\title{
The Effects of Functional Training on Some Biomotor Abilities and Physiological Characteristics in Elite Soccer Players
}

\author{
Bulent Turna ${ }^{1} \&$ Mahmut Alp $^{2}$ \\ ${ }^{1}$ Department of Movement and Training, Faculty of Sports, The University of Akdeniz, Antalya, Turkey \\ ${ }^{2}$ Department of Physical Education and Sports Training, Faculty of Sports, The University of Suleyman Demirel, \\ Isparta, Turkey \\ Correspondence: Bulent Turna, Akdeniz University, Faculty of Sport and Physical Education Antalya, Turkey. \\ E-mail: bulentturna@akdeniz.edu.tr
}

Received: December 4, 2019

Accepted: December 28, 2019 Online Published: January 6, 2020

doi:10.5539/jel.v9n1p164

URL: https://doi.org/10.5539/jel.v9n1p164

\begin{abstract}
Soccer game or a soccer match includes functional movements that require complex muscular balance including stopping, walking, jogging, sprint with dribbling, shooting and passing (Eniseler, 1994; Boyle, 2004). Functional training contribute to the different systems of the body through functional exercises performed in different parts of the body (covering the whole body, improving universal motor skills, applied in multiple motion planes) through intensive, short and constantly changing sessions. The aim of this study was to investigate the effects of functional training on some physiological and Biomotor Abilities in elite soccer players. Athletes were randomly divided into two groups as Traditional Training Group (TTG) and Functional Training Group (FTG). For eight weeks, TTG athletes were trained five days per week for classical soccer training while FTG athletes were trained with functional training two days a week in addition to this training. Table 4 shows that the effect of pre-test from post-test and present an adjusted post-test mean and determine the difference of the adjusted post-test mean of two groups. According to the ANCOVA results, differences were not found statistically significant $(\mathrm{p}>0.05)$. As a result, in this study, which aimed to investigate the effects of functional training on some physiological and bio-motor properties in elite soccer players, it was determined that functional training method had a positive effect on some physiological and bio-motor properties of pre- and post-test values in soccer players, however to determine the difference of the adjusted post-test mean of two groups, ANCOVA results show that differences were not found statistically significant.
\end{abstract}

Keywords: soccers, functional training, biomotor abilities, physiologic characteristics

\section{Introduction}

Different systems of the athletes need to be adapted to new circumstances in sport (Aktaş et al., 2019; Çakmakç1 et al., 2018, Özer \& Kılınç, 2011). As boxing requires high physical capacity and skill, boxing athlete must have many physical, motoric and biochemical factors together (Soslu et al., 2018). Functional training contribute to the different systems of the body through functional exercises performed in different parts of the body (covering the whole body, improving universal motor skills, applied in multiple motion planes) through intensive, short and constantly changing sessions (Crawford et al., 2018; Tibana et al., 2018). Functional training is unique due to being the combination of various methods including olympic weightlifting, strength training and body weight training combined with aerobic training (Feito et al., 2018; Mate-Munoz et al., 2017).

In the literature, applications formed as a form of functional training are common with different work-to-rest ratios with similar training contents (gymnastics, dumbbells, aerobic exercises, etc.) (Claudino et al., 2018; De Sousa et al., 2016). The greatest benefits of functional training are that running many systems in the body, increasing aerobic power and anaerobic capacity positively as well as the body composition with the potential to increase stamina, strength and force in muscles (Crawford et al., 2018; Feito et al., 2018; Mate-Munoz et al., 2017). Endurance is highly dependent on the aerobic capacity of the athlete and less on the anaerobic capacity (Soslu et al., 2019; Soslu et al., 2018). Functional training, while increasing the muscular endurance, hypertrophy, strength and strength of athletes simultaneously, also creates an excellent effect to improve aerobic power and anaerobic capacity (Crawford et al., 2018; Heinrich et al., 2012; Barfield et al., 2012). In the literature, it has been reported that static stretching exercises reduce the maximal muscle performance when performed 
before maximal muscle activities (Turna, 2017). The application of dynamic stretching exercises before functional training may prevent this loss of force. Furthermore, it is possible to change the movements to be implemented by the diversity inherent in functional training to improve the specific needs of a sport. One of the common problems in team sports is the decrease in performance caused by the lack of training time in a long competitive season (Miller et al., 2007). Considering that the increase in force would have a direct effect to the development of muscle strength (Haff et al., 2012), previous studies showed that functional training also had a potential to increase this property (Hermassi et al., 2017; Heinrich et al., 2012; De Sousa et al., 2016). If the multi-joint movements of the athlete, such as bending, stepping, pushing, pulling and rotating are restricted or cannot be performed whatsoever in sagittal, frontal and transversal planes. This means that the athlete is functionally insufficient and the performance is or will be adversely affected (Ratamess, 2011; Beckham \& Harper, 2010). Therefore, functional training programs should be designed to mimic the functional movements, or the movements performed in a person's daily life should be in harmony with the exercises (Weiss et al., 2010). According to Brill (2008), functional training combines lower and upper body movements, and more muscle and joint movements are involved in each movement. This philosophy, versus the traditional training that is based on the development of muscles in an isolated manner, supports the idea of functional exercise, which involves exercises based on the movement that will be applied. Other studies indicate that functional training is beneficial because all natural movements occur in different motion planes and in multiple joints, rather than isolation.

Determining the differences between functional and traditional training programs can help to better understand the role of resistance trainings in maintaining physical health and other wellness benefits (Weiss et al., 2010). Traditional exercise programs are thought to include exercises that isolate specific muscles to increase muscle strength more effectively (McGill et al., 2009). In accordance with this philosophy, the focus of a traditional exercise program is to increase the strength or stamina of a given muscle or muscle group, regardless of their movements in daily or sporting activities. Traditional, machine-based and free-weight exercise programs that restrict movement across a plane of motion (usually sagittal) may have a lower impact compared to real-life activities which occur in more than one plane (Whitehurst et al., 2005). Although the studies conducted on the machines are considered to be safe, it has been reported that they are insufficient in balance, stability and proprioceptive systems (Boyle, 2004). Since accepting a movement as functional depends on the coordination of the movement, i.e., the ability of the neuromuscular system to function effectively, the development of abilities such as balance, proprioception, coordination and stabilization are among the requirements of functional training (Beckham \& Harper, 2010).

Functional training method is used in soccer as in many branches of sports and its various effects are examined. The level of physical, physiological, psychological and bio-motor properties plays an important role in performance in sport branches for example soccer (Acar, 2000; Tiryaki, 1991; Tatlici et al., 2019; Ünlü et al., 2018; Çakmakçı et al., 2019). To reach the desired level of physiological factors required for soccer players, bio-motor properties should be taken into consideration with the energy metabolisms active in soccer games and training specific to soccer should be applied (Eniseler, 1994). In this case, not only physiological but also bio-motor properties of the athlete should be developed for sportive performance (Kürkçü, et al., 2009). Nowadays short times difference determines teams or players winner (Tatlıc1 et al., 2018). Soccer game or a soccer match includes functional movements that require complex muscular balance including stopping, walking, jogging, sprint with dribbling, shooting and passing (Eniseler, 1994; Boyle, 2004). As a result, according to the literature, functional training exercises have various effects. For this reason, the inclusion of functional trainings appropriate to the type of sports to be performed is a factor that affects performance positively.

In the light of these informations, the aim of this study was to investigate the bio-motor and physiological effects of the functional training method on soccer players.

\section{Method}

\subsection{Participants}

20 professional soccer players who play in the 3rd League of Turkish Soccer Federation joined to the study and fill out the 'Informed Volunteer Consent Form'. Athletes were randomly divided into two groups as Traditional Training Group (TTG) and Functional Training Group (FTG). There values were taken in results of mean age of FTG 25.2 \pm 3.36 , TTG 22.90 \pm 2.02 years; mean height of FTG $181.8 \pm 4.44$, TTG $180.9 \pm 6.06 \mathrm{~cm}$; mean weight of FTG 78.7 \pm 5.96 , TTG $76.80 \pm 6.44 \mathrm{~kg}$; mean sport age of FTG $6.40 \pm 3.09$, TTG $4.40 \pm 2.71$ years.

\subsection{Procedure}

For eight weeks, TTG athletes were trained five days a week for traditional soccer training while FTG athletes were trained with functional training two days a week in addition to this training. When applying the FTG 
trainings, in addition to the program and the exercises with the example given in Table 1 were added to the training on Tuesdays and Thursdays for 20 minutes.

Table 1. Weekly training program of FTG

\begin{tabular}{llll}
\hline Exercises & Sets & Reps & Notes \\
\hline Sit Ups & $3-5$ & $1 \mathrm{~min}$ & Rest $1-2$ min between sets \\
Medicine Ball Slams & $3-5$ & $1 \mathrm{~min}$ & Rest $1-2$ min between sets \\
Deadlifts & 3 & 5 & Performed as a short circuit, with 2 min. rest between sets \\
Bench Press & 3 & 5 & \\
Sprints & 3 & $20 \mathrm{~m}$ & \\
Back Squats & 3 & 4 & Rest 30 s between exercises, and 3 min. between sets \\
Box Jumps & 3 & 4 & \\
Lateral Lunge with Overhead Press & $3-5$ & $1 \mathrm{~min}$ & Rest 1 min between sets \\
lunge & 3 & $3 \mathrm{~min}$ & Rest 1 min between sets \\
Battle Rope Waves & 3 & $3 \mathrm{~min}$ & Rest 1 min between sets \\
Walking Plank & 3 & $3 \mathrm{~min}$ & Rest 1 min between sets \\
Burpee & 3 & $3 \mathrm{~min}$ & Rest 1 min between sets \\
Squat Chop & 3 & 15 & Rest $1: 1$ between sets \\
Squat Lift & 3 & 15 & Rest $1: 1$ between sets \\
Curl Up MedBall Throw & 3 & 15 & Rest $1: 2$ between sets \\
Squat with mediball Slam & 3 & $3 \mathrm{~min}$ & Rest 1 min between sets \\
\hline
\end{tabular}

Table 2. Weekly training program of TTG

\begin{tabular}{|c|c|}
\hline Days & Program \\
\hline Monday & Lactic elimination training \\
\hline Tuesday & $\begin{array}{l}10 \text { min. warm-up run, } 5 \text { min dynamic flexibility training, } 15 \text { min speed training, } 30 \text { min. match, } 10 \text { min static stretching } \\
\text { training }\end{array}$ \\
\hline Wednesday & $10 \mathrm{~min}$. warm-up running, $15 \mathrm{~min}$. flexibility training, $25 \mathrm{~min}$. tactical training, $20 \mathrm{~min}$ match, 10 min recovery run \\
\hline Thursday & 10 minwarm-up run, 15 min collective agility training, 20 min.plyometric training, 20 min tactical training \\
\hline Friday & $\begin{array}{l}10 \text { min. warm-up running, } 15 \text { min combined flexibility training, } 20 \text { min shooting training, } 25 \text { min. tactical training, } 10 \text { min. } \\
\text { cooling down }\end{array}$ \\
\hline Saturday & Rest \\
\hline Sunday & Event \\
\hline
\end{tabular}

\subsection{Tests}

2.3.1 Vertical Jump Test: Free vertical jump test was applied to athletes. The best results were recorded as "cm" from tool measuring digitally. "Takei jumper meters" was used with measurement capacity between $5 \mathrm{~cm}$ to 99 $\mathrm{cm}$, showing the distance digitally by leaping with waist stuck.

2.3.2 Hand Grip Strength Test: Grip strength was performed with “Takei brand hand dynamometer" on the right and left hand. During the measurement, the athlete stands upright. The measurement was carried out without bending the arm, contacting the body and slightly distant position from the body. The same was repeated three times for the right and left arm. The best value was recorded in kilograms $(\mathrm{kg})$.

2.3.3 Back-Leg Strength Test: Back and leg strength was performed with "Takei force dynamometer". During the measurement, the players complete their traction with only leg forces by bending the legs at a $45^{\circ}$ angle from the knees. The measurement was repeated 3 times and the best score was recorded.

2.3.4 Flexibility Test: The most remote spots flexibility distances were recorded with students' sit-reach flexibility test. General warm-up was done for athletes with leg and back muscles before this test. Measurements were repeated 3 times and the value was recorded.

2.3.5 $30 \mathrm{~m}$ Sprint Test: This test was performed with soccer players with spikes, shorts and uniforms on a dirt surface. The results were taken with photocell device that worked on light sensitivity. The footballers were allowed to depart 2 meters away from the start line.

2.3.6 Resting Heart Rate Test: The heart rate was recorded with electronic sphygmomanometer when resting values were on stable level.

2.3.7 Systolic and Diastolic Blood Pressure Test: The blood pressure was recorded with electronic 
sphygmomanometer when resting values were on stable level.

2.3.8 Anaerobic Power Test: Anaerobic Power of player calculated with Lewis formula.

Anaerobic Power $($ Watt $/ \mathrm{s})=\sqrt{ } 4.9 \times$ Weight $(\mathrm{kg}) \mathrm{x} \sqrt{ }$ Score of Vertical Jump $(\mathrm{m}) \times 9.81$

\subsection{Data Analysis}

The analysis of the data was done in the Statistical Package Program by using the Descriptive Statistics and "ANCOVA" for determining the effect of pretest from post test and the difference of the posttest mean of two groups. The results were evaluated according to " $p<0.05$ " significance level.

\section{Findings}

Table 3. Descriptive statistics of groups

\begin{tabular}{llllll}
\hline & & TTG & & FTG & \\
\hline \multirow{4}{*}{ Vertical Jump } & Test Sequence & Mean & SD & Mean & SD \\
& Pre-Test & 62.4 & 4.99 & 61.4 & 7.86 \\
Right Hand Grip & Post-Test & 62.9 & 4.33 & 64.7 & 8.13 \\
& Pre-Test & 43.84 & 5.71 & 43.29 & 3.71 \\
Left Hand Grip & Post-Test & 44.1 & 5.42 & 43.99 & 3.7 \\
& Pre-Test & 42.71 & 5.39 & 42.42 & 5.49 \\
Back Strength & Post-Test & 42.78 & 5.76 & 42.95 & 5.68 \\
& Pre-Test & 99.86 & 15.21 & 98.2 & 14.29 \\
Leg Strength & Post-Test & 105.5 & 14.83 & 103.35 & 13.94 \\
& Pre-Test & 98.6 & 18.29 & 101.46 & 11.01 \\
Flexibility & Post-Test & 100.32 & 16.42 & 105.75 & 10.61 \\
30 m Sprint & Pre-Test & 32.2 & 8.01 & 33.2 & 5.3 \\
& Post-Test & 32.7 & 7.8 & 33.3 & 5.07 \\
Systolic Blood Pressure & Pre-Test & 3.97 & .10 & 4.106 & .15 \\
& Post-Test & 3.93 & .10 & 3.99 & .11 \\
Diastolic Blood Pressure & Pre-Test & 11.7 & .29 & 11.82 & .38 \\
& Post-Test & 11.72 & .26 & 11.85 & .33 \\
Resting Heart Rate & Pre-Test & 6.63 & .36 & 6.95 & .57 \\
& Post-Test & 6.69 & .35 & 6.88 & .49 \\
Anaerobic Power & Pre-Test & 62.1 & 1.44 & 63.7 & 2.98 \\
& Post-Test & 62 & 2.05 & 62.3 & 3.33 \\
& Pre-Test & 1342.55 & 131.39 & 1364.22 & 151.17 \\
& Post-Test & 1348.13 & 128.66 & 1402.02 & 150.9 \\
\hline
\end{tabular}

Table 4. ANCOVA results of groups

\begin{tabular}{llllll}
\hline Tests & Test Sequence & Type III Sum of Squares & Mean Square & F & p \\
\hline Vertical Jump & Pre-Test & .983 & .983 & 3.121 & .138 \\
& Post-Test & 1.006 & 1.006 & 3.195 & .134 \\
Right Hand Grip & Pre-Test & .144 & .144 & .457 & .529 \\
& Post-Test & .267 & .267 & .847 & .400 \\
Left Hand Grip & Pre-Test & .201 & .201 & .637 & .461 \\
& Post-Test & .222 & .222 & .705 & .439 \\
Leg Strength & Pre-Test & .002 & .002 & .007 & .937 \\
& Post-Test & .001 & .001 & .002 & .970 \\
Back Strength & Pre-Test & .241 & .241 & .764 & .422 \\
& Post-Test & .108 & .108 & .343 & .584 \\
30 m Sprint & Pre-Test & .019 & .019 & .060 & .816 \\
& Post-Test & .210 & .210 & .666 & .452 \\
Anaerobic Power & Pre-Test & 1.039 & 1.039 & 3.300 & .129 \\
& Post-Test & 1.028 & 1.028 & 3.264 & .131 \\
\hline
\end{tabular}

Table 4 shows that the effect of pre-test from post-test and present an adjusted post-test mean and determine the difference of the adjusted post-test mean of two groups. According to the ANCOVA results, differences were not found statistically significant ( $\mathrm{p}>0.05)$. 


\section{Discussion}

Scientific studies conducted by applying functional training method showed that functional training affects various physiological and bio-motoric properties. Our research show statistically significant differences between pre- and post-test values but ANCOVA results not.

It has been suggested that functional training can be as effective as traditional resistance training to increase muscle strength, power and stamina (Hermassi et al., 2017; Claudino et al., 2018; De Sousa et al., 2016; Barfield et al., 2012). Researchers compared the cardiovascular effects of the training called "Cindy" (continuous set consisting of 5 pull-ups, 10 push-ups and 15 body-weight squat for 20 minutes) and the the cardiovascular effects of the 20 -minute run at the $90 \%$ of the maximum heart rate. In the study, high levels of oxidative and metabolic stress were observed in both training methods (Kliszczewicz et al., 2015). They have reported that there was no significant difference between oxidative and metabolic stress values.

De Sousa et al. (2016), in their study, examined the fitness differences between the participants who had received recreational CrossFit at least two to three sessions a week for at least one year and those who had received resistance training. According to the researchers, both groups achieved average results for male subjects of the same age in a pull-up test, however it was shown that the results of CrossFit group were slightly better in the counter-jumping scores, so the difference was not significant.

In a study conducted with university students, the efficacy of a traditional training program was compared with the functional training. As a result of the study, significant improvements were obtained in the endurance of lower body muscles in functional training group. Although the functional training program (CrossFit) was not effective in increasing muscle strength and power as the traditional training group, $60 \%$ of the participants improved their lower body strengths, and about half of these had also improvements in upper body strength (Barfield et al., 2012).

However, Weiss et al. (2010), in their study to determine the similar effects of functional training with traditional training on muscle strength, stamina, flexibility, agility, balance and anthropometric properties of young adults, have stated that they could not obtain clear results on which method was more effective. Kibele and Behm (2009) also found similar results in a 7-week functional study program.

In the literature, there are studies examining the effects of functional training method on soccer performance. Boztepe (2018) investigated the effect of functional training on athletic performance in young soccer players. The researcher has reported that there were no statistically significant differences in pre-test results between the functional training group (FTG), the traditional training group (TTG) and the control group (CG), however there were statistically significant differences in terms of FMS total score, speed, agility, right dynamic balance and left dynamic balance performance values. According to the results reported by Boztepe (2018), young soccer players also stated that the functional training method was more effective in improving athletic performance compared to the traditional training method. The results reported that supports the results obtained in the present study which indicated that functional training had positive effects on the bio-motor properties.

Heinrich et al. (2012) showed that a functional training program was more effective than the traditional army training program to improve muscle strength. Over an eight-week period, participants in the functional training group underwent 15 different high-intensity exercises consisting of exercises focused on force, strength, speed and agility. The exercises included Olympic weight-lifting, upper and lower body plyometric exercises each performed for 60 to 90 seconds, in addition to core exercises (Heinrich et al., 2012). In contrast to those previously reported (Barfield et al., 2012), in the functional training group, an increase in upper body strength was achieved in the bench press 1RM (single repeat maximum value) test. Similar to the findings reported by de Sousa et al. (2016), albeit not statistically significant, the functional training program achieved better results in vertical jump performance compared to the traditional army training group. Goss et al. (2009) have reported that, after a 6-week functional study program based on functional movements, significant progress was achieved in the one-leg leap, kick and vertical jump performances. These studies defined the benefits of functional trainings in large groups but not in small groups.

There are also studies examining the effects of functional training method on other sports branches. Yildiz and Pinar (2013), according to the findings of the study performed on children tennis players, found that functional training method increased the vertical jump, speed, flexibility, agility, balance and functional capacity of the athletes better than the traditional training method. Song et al. (2014) applied a 16-week functional training program on baseball players. According to the findings of the study, functional training increased the strength and flexibility of baseball players. Atabaş and Kumartaşlı (2017) investigated the effect of 8-week functional training on strength, flexibility and swimming performance in young male swimmers. As a result, the researchers 
have stated that 8-week functional training exercises applied to swimmers improved the force performance however did not provide a significant improvement in swimming and flexibility performances.

\section{Conclusion}

As a result, in this study, which aimed to investigate the effects of functional training on some physiological and bio-motor properties in elite soccer players, it was determined that functional training method had effects on some physiological and bio-motor properties of pre- and post-test values in soccer players, however to determine the difference of the adjusted post-test mean of two groups, ANCOVA results show that differences were not found statistically significant.

Current results show that functional training can be an important strategy in increasing muscle strength and endurance that create motoric properties in younger age groups and young people, and that training can be applied appropriately to target these training components. For future studies, it can be said that functional training contributes to multiple adaptation components that require simultaneous development of performance, especially in young groups. It is thought that functional trainings can be a time-efficient strategy in a sports branch where all condition features such as football should be at an optimum level. The high number of athletes selected may provide a better visualization of the effects of functional training. In this context, coaches are advised to include functional training in addition to football training at the beginning and end of the season.

\section{References}

Acar, M. F. (2000). Kurumsal Temelleriyle Futbolda Çocuk ve Gençlerin Antrenmanları (p. 148). Meta Basım, İzmir.

Aktaş, S., Tatlici, A., \& Çakmakçi, O. (2019). Determination of Isokinetic Strength of Upper and Lower Body of Elite Male Boxers. Turkish Journal of Sport and Exercise, 21(2), 188-191. https://doi.org/10.15314/tsed.600645

Atabaş, E. G., \& Kumartaşlı M. (2017). Erkek Yüzücülere Uygulanan 8 Haftalık Fonksiyonel Antrenman Yaklaşımının Kuvvet, Esneklik Ve Yüzme Performanslarına Etkisi. Yüksek Lisans Tezi, Süleyman Demirel Üniversitesi, Sağlık Bilimleri Enstitüsü, Spor Bilimleri Anabilim Dalı.

Barfield, J. P., Channell, B., Pugh, C., Tuck, M., \& Pendel, D. (2012). Format of basic instruction program resistance training classes: Effect on fitness change in college students. Physical Educator, 69(4), 325.

Beckham, S. G., \& Harper, M. (2010). Functional training: fad or here to stay? ACSM's Health and Fitness Journal, 14(6), 24-30. https://doi.org/10.1249/FIT.0b013e3181f8b3b7

Boyle, M. (2001). Functional training for sports. USA, Human Kinetics.

Boyle, M. (2004). Functional training for sports. Human Kinetics Publishers.

Boztepe, A. (2018). Genç Futbolcularda Fonksiyonel Antrenmanın Atletik Performansa Etkisinin Değerlendirilmesi. Yüksek Lisans Tezi, Marmara üniversitesi,Sağlık Bilimleri Enstitüsü, Beden Eğitimi ve Spor Anabilim Dalı.

Brill, P. A. (2008). Exercise your independence: functional fitness for older adults. Journal of Aging and Physical Activity, 16, S88-S89.

Çakmakçı, E., Tatlıcı, A., Kahraman, S., Yılmaz, S., Ünsal, B., \& Özkaymakoğlu, C. (2019). Does once-a-week boxing training improve strength and reaction time? Uluslararast Spor Egzersiz ve Antrenman Bilimi Dergisi, 5(2), 88-92. https://doi.org/10.18826/useeabd.552086

Çakmakçi, E., Tatlici, A., \& Yirmibeş, B. (2018). Comparıson Of Some Performance Parameters of Physıcally Actıve Mentally Retarded and Inactive Mentally Retarded Individuals. European Journal of Physical Education and Sport Science, 4(12), 49-57.

Claudino, J. G., Gabbett, T. J., Bourgeois, F., de Sá Souza, H., Miranda, R. C., Mezêncio, B., \& Amadio, A. C. (2018). Crossfit overview: systematic review and meta-analysis. Sports Medicine-Open, 4(1), 11. https://doi.org/10.1186/s40798-018-0124-5

Crawford, D., Drake, N., Carper, M., DeBlauw, J., \& Heinrich, K. (2018). Are changes in physical work capacity induced by high-1ntensity functional training related to changes in associated physiologic measures? Sports, 6(2), 26. https://doi.org/10.3390/sports6020026

De Sousa, A. F., dos Santos, G. B., dos Reis, T., Valerino, A. J., Del Rosso, S., \& Boullosa, D. A. (2016). Differences in physical fitness between recreational crossfit ${ }^{\circledR}$ and resistance trained individuals. Journal of 
Exercise Physiology Online, 19(5).

Drake, N., Smeed, J., Carper, M. J., \& Crawford, D. A. (2017). effects of short-term crossfit ${ }^{\mathrm{TM}}$ training: a magnitude-based approach. Journal of Exercise Physiology Online, 20(2).

Eniseler, N. (1994). Futbolu etkileyen fizyolojik faktörler. Futbol Bilim ve Teknoloji Dergisi, 1(1), 10-12.

Ersöz, M. (2016). Farklı yaş kategorilerindeki futbolcuların fonksiyonel hareket değerlendirme test (FMS) sonuçlarının sürat, esneklik, çeviklik, patlayıcı kuvvet (güç) özellikleri karşılaştırılması. Yüksek Lisans Tezi, İstanbul Gelişim Üniversitesi Sağlık Bilimleri Enstitüsü.

Feito, Y., Heinrich, K., Butcher, S., \& Poston, W. (2018). High-intensity functional training (HIFT): definition and research implications for improved fitness. Sports, 6(3), 76. https://doi.org/10.3390/sports6030076

Goss, D. L., Christopher, G. E., Faulk, R. T., \& Moore, J. (2009). Functional training program bridges rehabilitation and return to duty. Journal of Special Operations Medicine: A Peer Reviewed Journal for SOF Medical Professionals, 9(2), 29-48.

Haff, G. G., \& Nimphius, S. (2012). Training principles for power. Strength and Conditioning Journal, 34(6), 212. https://doi.org/10.1519/SSC.0b013e31826db467

Heinrich, K. M., Spencer, V., Fehl, N., \& Carlos Poston, W. S. (2012). Mission essential fitness: comparison of functional circuit training to traditional Army physical training for active duty military. Military Medicine, 177(10), 1125-1130. https://doi.org/10.7205/MILMED-D-12-00143

Hermassi, S., Wollny, R., Schwesig, R., Shephard, R. J., \& Chelly, M. S. (2017). Effects of in-season circuit training on physical abilities in male handball players. The Journal of Strength \& Conditioning Research.

Kibele, A., \& Behm, D. G. (2009). Seven weeks of instability and traditional resistance training effects on strength, balance and functional performance. The Journal of Strength \& Conditioning Research, 23(9), 2443-2450. https://doi.org/10.1519/JSC.0b013e3181bf0489

Kliszczewicz, B., John, Q. C., Daniel, B. L., Gretchen, O. D., Michael, E. R., \& Kyle, T. J. (2015). Acute exercise and oxidative stress: Crossfit ${ }^{\mathrm{TM}}$ vs. Treadmill bout. Journal of Human Kinetics, 47(1), 81-90. https://doi.org/10.1515/hukin-2015-0064

Kürkçü, R., Afyon, Y. A., Yaman, Ç., \& Özdağ, S. (2009). Comparison of some physical and physiologic properties of soccer players and badminton players of 10-12 years old group. Uluslararası Insan Bilimleri Dergisi, 6(1), 547-556.

Maté-Muñoz, J. L., Lougedo, J. H., Barba, M., García-Fernández, P., Garnacho-Castaño, M. V., \& Domínguez, R. (2017). Muscular fatigue in response to different modalities of crossfit sessions. PloS One, 12(7), e0181855. https://doi.org/10.1371/journal.pone.0181855

McGill, S. M., Karpowicz, A., Fenwick, C. M., \& Brown, S. H. (2009). Exercises for the torso performed in a standing posture: spine and hip motion and motor patterns and spine load. The Journal of Strength \& Conditioning Research, 23(2), 455-464. https://doi.org/10.1519/JSC.0b013e3181a0227e

Miller, T. A., Thierry-aguilera, R., Congleton, J. J., Amendola, A. A., Clark, M. J., Crouse, S. F., \& Jenkins, O. C. (2007). Seasonal changes in VO2max among division 1A collegiate women soccer players. The Journal of Strength \& Conditioning Research, 21(1), 48-51. https://doi.org/10.1519/00124278-200702000-00009

Özer, Ö., \& Kılınç, F. (2012). Comparison of strength, speed and flexibility performance of elite individual and team athletes. International Journal of Human Sciences, 9(1), 360-371.

Ratamess, N. A. (2011). ACSM's foundations of strength training and conditioning (pp. 13-20). Wolters Kluwer Health/Lippincott Williams \& Wilkins.

Song, H. S., Woo, S. S., So, W. Y., Kim, K. J., Lee, J., \& Kim, J. Y. (2014). Effects of 16-week functional movement screen training program on strength and flexibility of elite high school baseball players. Journal of Exercise Rehabilitation, 10(2), 124. https://doi.org/10.12965/jer.140101

Soslu, R., Guler, M., Ömer, Ö., Devrilmez, M., Cincioğlu, G., Dogan, A. A., \& Esen, H. T. (2018). Effect of Acute Fatigue on Static Balance in Boxers. Sportive, 1(1), 19-30.

Soslu, R., Özer, Ö., \& Çuvalcioğlu, İ. C. (2018). The Effects of Core Training on Basketball Athletes' Antioxidant Capacity. Journal of Educationand Training Studies, 6(11), $128-134$. https://doi.org/10.11114/jets.v6i11.3454

Soslu, R., Özer, Ö., Güler, M., \& Doğan, A. A. (2019). Is there any Effect of Core Exercises on Anaerobic 
Capacity in Female Basketball Players? Journal of Educationand Training Studies, 7(3), 99-105. https://doi.org/10.11114/jets.v7i3.3959

Tatlıcı, A., Çakmakçı, E., Yılmaz, S., \& Arslan, F. (2018) Comparison of Visual Reaction Values of Elite Deaf Wrestlers and Elite Normally Hearing Wrestlers. Turkish Journal of Sport and Exercise, 20(2), 63-66. https://doi.org/10.15314/tsed.440813

Tatlici, A., \& Cakmakci, O. (2019). The effects of acute dietary nitrate supplementation on anaerobic power of elite boxers. Medicina Dello Sport, 72(2), 225-233.

Tibana, R., de Sousa, N., Cunha, G., Prestes, J., Fett, C., Gabbett, T., \& Voltarelli, F. (2018). Validity of session rating perceived exertion method for quantifying internal training load during high-intensity functional training. Sports, 6(3), 68. https://doi.org/10.3390/sports6030068

Tiryaki, Ş. (1991). Sportif performans ile Edwars kişisel tercih envanteri verilerinin ilişkisi. Spor Bilimleri Dergisi, 2(2), 32-37.

Turna B. (2017). Dinamik ve statik germe egzersizlerinin elit erkek hentbolculartn bazı biyomotorik özelliklerine akut etkisi. ISBN: 978-613-7-37894-6, Lap Lambert Academic Publishing, Mauritius.

Ünlü, G., \& Tatlıcı, A. (2018). Elit Güreşçilerde Proprioseptif Nöromuskuler Fasilitasyon (Pnf) Uygulamalarının Dinamik Denge Performansına Akut Etkileri. Sportif Bakış: Spor ve Eğitim Bilimleri Dergisi, 57-63.

Yıldız S., \& Pınar S., (2013). Çocuk Tenisçilerde Fonksiyonel Antrenman Yaklaşımı. Doktora Tezi, Marmara Üniversitesi, Sağlık Bilimleri Enstitüsü.

Weiss, T., Kreitinger, J., Wilde, H., Wiora, C., Steege, M., Dalleck, L., \& Janot, J. (2010). Effect of functional resistance training on muscular fitness outcomes in young adults. Journal of Exercise Science \& Fitness, 2, 113-122. https://doi.org/10.1016/S1728-869X(10)60017-2

Whitehurst, M. A., Johnson, B. L., Parker, C. M., Brown, L. E., \& Ford, A. M. (2005). The benefits of a functional exercise circuit for older adults. Journal of Strength and Conditioning Research, 19(3), 647. https://doi.org/10.1519/00124278-200508000-00027

\section{Copyrights}

Copyright for this article is retained by the author, with first publication rights granted to the journal.

This is an open-access article distributed under the terms and conditions of the Creative Commons Attribution license (http://creativecommons.org/licenses/by/4.0/). 